\title{
Evaluation of severity scoring systems in patients with severe community acquired pneumonia
}

\author{
KATERINA SPASOVSKA ${ }^{1}$, KRSTO GROZDANOVSKI ${ }^{1}$, ZVONKO MILENKOVIC $^{1}$, MILE BOSILKOVSKI ${ }^{1}$, \\ MARIJA CVETANOVSKA ${ }^{1}$, NIKOLA KUZMANOVSKI ${ }^{1}$, KOSTA KAPSAROV ${ }^{1}$, EMILIJA ATANASOVSKA ${ }^{2}$ \\ ${ }^{1}$ University Clinic for Infectious Diseases, Faculty of Medicine, University of Ss Cyril and Methodius, \\ Bul. Majka Tereza br 17, 1000 Skopje, North Macedonia \\ ${ }^{2}$ Institute of Preclinical and Clinical Pharmacology and Toxicology, Faculty of Medicine, University of Ss Cyril and Methodius, \\ ul. 50ta Divizija 6, 1000 Skopje, Republic of North Macedonia
}

\begin{abstract}
Background. The aim of this study was to evaluate the ability of severity scoring systems to predict 30-day mortality in patients with severe community-acquired pneumonia.

Methods. The study included 98 patients aged $\geq 18$ years with community acquired pneumonia hospitalized at the Intensive Care Unit of the University Clinic for Infectious Diseases in Skopje, Republic of North Macedonia, during a 3-year period. We recorded demographic, clinical and common biochemical parameters. Five severity scores were calculated at admission: CURB 65 (Confusion, Urea, Respiratory Rate, Blood pressure, Age $\geq 65$ years), SCAP (Severe Community Acquired Pneumonia score), SAPS II (Simplified Acute Physiology Score), SOFA (Sequential Organ Failure Assessment Score) and MPM (Mortality Prediction Model). Primary outcome variable was 30-day in-hospital mortality.

Results. The mean age of the patients was $59.08 \pm 15.76$ years, predominantly males $(68 \%)$. The overall 30-day mortality was 52\%. Charlson Comorbidity index was increased in non-survivors $(3.72 \pm 2.33)$ and was associated with the outcome. All severity indexes had higher values in patients who died, that showed statistical significance between the analysed groups. The areas under curve (AUC) values of the five scores for 30-day mortality were $0.670,0.732,0,726,0.785$ and 0.777 , respectively.

Conclusion. Widely used severity scores accurately detected patients with pneumonia that had increased risk for poor outcome, but none of them individually demonstrated any advantage over the others.
\end{abstract}

Key words: community-acquired pneumonia, intensive care, severity scores, prognosis, outcome.

\section{What is new? What is important?}

Evaluation of severity scoring systems in patients with community-acquired pneumonia presents a valuable starting point for the general assessment of the disease and hence enabling a better management of the patients, based on an accurately assessed severity of the disease.

\section{INTRODUCTION}

Community acquired pneumonia (CAP) is the most common potentially fatal infectious disease and one of the leading causes for hospitalization, high health care costs and death worldwide. Approximately $20 \%$ of all cases are admitted to hospital and 8-36\% among them require treatment in the intensive care unit (ICU) due to disease severity $[1,2,3]$. Today severe community acquired pneumonia is considered as a separate clinical entity with specific epidemiological characteristics, different distribution of aetiological agents, increased risk of complications such as acute respiratory distress syndrome (ARDS) and septic shock, as well as a high mortality rate $[4,5]$. Therefore, accurate assessment of disease severity and early prediction of poor outcome is of crucial importance for successful management [6,7]. Eminent international societies such as Infectious Diseases Society of America (IDSA), American Thoracic Society (ATS), British Thoracic Society (BTS) and European Respiratory Society (ERS) have published guidelines for community acquired pneumonia that recommend a clinical approach based on the assessment of the disease severity [8]. Thus, several severity assessment tools and scoring systems were designed to enable patient stratification based on predicted mortalities. The most frequently used are the Pneumonia severity index (PSI) [9], CURB-65 (Confusion, Urea, Respiration rate, Blood Pressure, Age $\geq 65$ years) [10], Severe 
Community Acquired Pneumonia Score (SCAP) [11] as well as the criteria of the American Thoracic Society [12]. The purpose of these scoring models is to guide the clinical decision on the site of care upon the diagnosis and to assess the prognosis of community acquired pneumonia. Patients with the highest score have an increased risk of fatal outcome and should receive an intensive care treatment as severe pneumonia. In addition, in critically ill patients admitted at intensive care units, regardless the diagnosis, assessment of disease severity and mortality prediction is performed by commonly used severity indexes such as SAPS II (Simplified Acute Physiology Score) [13], SOFA (Sequential Organ Failure Assessment score) [14], APACHE II (Acute Physiology and Chronic Health Evaluation II) [15] and MPM (Mortality Prediction Model) [16].

At the ICU Department of the University Clinic for Infectious Diseases and Febrile Conditions, community acquired pneumonia is the second most frequently treated disease and is a leading cause of sepsis and acute respiratory distress syndrome, with a high mortality rate [17]. However, an evaluation of mortality prediction capacities of most commonly used severity indexes for this disease has not been conducted yet.

The aim of this study is to evaluate the ability of severity scoring systems to predict 30day mortality in patients with severe communityacquired pneumonia.

\section{MATERIAL AND METHODS}

The study included 98 patients aged $\geq 18$ years with community acquired pneumonia consecutively admitted at the Intensive Care Unit of University Clinic for Infectious Diseases in Skopje, Republic of North Macedonia. It was a retrospective, observational and group comparison study that took place from January 2016 to December 2018. The hospital ethical committee approved the research. Community acquired pneumonia was defined in accordance with IDSA/ATS guidelines as presence of at least one of the clinical symptoms of cough, sputum, fever, dyspnea, and pleural chest pain, plus at least more than one finding of coarse crackles on auscultation or elevated inflammatory biomarkers, in addition to a new infiltrate on chest radiography. Exclusion criteria were: age <18 years, acquired immune deficiency syndrome, hospital-acquired pneumonia or nursing home residency. Outcome was defined as survival or death during the 30 days of hospital treatment. For the purpose of this analysis, patients were divided into two groups according to the outcome: survivors and non-survivors. For all patients the demographic data, comorbidities, clinical findings and most common laboratory tests were recorded. Severity indexes such as CURB-65, SCAP, SAPS II, MPM and SOFA score were calculated during the first 24 hours of admission. Charlson Comorbidity Index was calculated to predict the 10-year survival. The set of analysed clinical parameters included: mental status (assessed with Glasgow Coma Scale), body temperature, respiratory rate, blood pressure, heart rate, and signs of shock (defined as mean arterial pressure $<65 \mathrm{mmHg}$ regardless of the adequate therapy with intravenous fluids). Biochemical parameters that were measured upon admission were: blood count, fasting glucose levels, serum urea, creatinine, electrolytes, lactate-dehydrogenase, bilirubin level, hepatic transaminases, serum albumin, C-reactive protein, procalcitonin and gas analyses. All laboratory tests were performed by standard methods in the biochemical laboratory at the hospital. Patients received treatment in accordance with the national CAP guidelines and for the purpose of this study they were monitored up to 30 days of hospitalization.

\section{Statistical analysis}

Continuous variables were expressed as mean and standard deviation (SD), whereas categorical variables were expressed as frequency (percentage), as appropriate. Continuous variables were analysed by Student's t-test and categorical variables were assessed with the Chi-square test. Univariate analysis was performed for predicting 30-day mortality. Multivariate analysis using stepwise logistic regression analysis was conducted for all variables that were found to have a $P$ value of $\leq 0.1$ on univariate analysis. To assess the usefulness of existing pneumonia severity scores for predicting the prognosis of CAP, we performed Receiver Operating Characteristic (ROC) curve analysis with application of the Bonferroni correction for twoway comparisons of the AUCs of pneumonia severity scores. All statistical tests were two-tailed and value of $P<0.05$ was considered as significant. Data were analysed with SPSS 23.0 software (SPSS, Chicago, IL). 


\section{RESULTS}

A total of 98 patients were enrolled in the study. The mean age was $59.08 \pm 15.76$ years and $68 \%$ of the patients were males. The overall 30-day mortality rate was $52 \%$. Charlson Comorbidity Index in non-survivors was $3.72 \pm 2.33$ that showed significant association with the outcome. Patient who died had shorter duration of ICU stay, in average of 11 days. The highest frequency of patients was registered in winter and spring, $42 \%$ and 25 $\%$, respectively. The baseline characteristics of the study population, stratified by the outcome, are presented in Table 1.

Clinical findings observed at admission in ICU such as mental status, body temperature, respiratory rate, heart rate and signs of shock are provided in Table 2. Septic shock and encephalopathy were clinical parameters that significantly associated with the outcome.

Table 3 presents the biochemical parameters analysed in the study population, stratified into two groups according to the outcome. Non-survivors had higher leukocyte count, elevated serum levels of urea, glucose, aminotransferases, LDH and lactates. Both survivors and non-survivors had increased values of inflammatory markers such as C-reactive protein and procalcitonin at admission, but their values were not significantly associated with the outcome. Blood gas analyses showed that the deceased patients had lower $\mathrm{pH}$ value and low $\mathrm{PaO}_{2} / \mathrm{FiO}_{2}$ ratio, presenting worse respiratory function in this group of critically ill patients.

The values of severity scoring systems SAPS II, SOFA, MPM, CURB 65 and SCAP for both survived and non-survivors are shown in Table 4. All evaluated indexes are significantly different between the groups, i.e. the deceased patients had higher values in every score. ROC analysis was performed to compare the predictive values of the severity indexes and curves are presented on Figure 1. Due to the small number of patients in which SCAP score was calculated, a ROC curve was not calculated for this score and was excluded from the analysis. The analysis showed that all indexes have area under the curve (AUC) above 0.5 presenting that they all have good predicting ability. The highest value of AUC was measured for MRM0 score and the lowest was obtained for CURB-65 (Table 5).

Table 1

Baseline characteristics of study population stratified by the outcome

\begin{tabular}{|c|c|c|c|}
\hline & $\begin{array}{c}\text { Survivors } \\
\mathrm{n}=47\end{array}$ & $\begin{array}{l}\text { Non-survivors } \\
\mathrm{n}=51\end{array}$ & $\mathrm{P}$-value \\
\hline Age (years; mean $\pm \mathrm{SD}^{\mathrm{a}}$ ) & $56.43 \pm 13.25$ & $61.53 \pm 17.54$ & 0.10 \\
\hline $\begin{array}{l}\text { Male (n, \%) } \\
\text { Female (n, \%) }\end{array}$ & $\begin{array}{l}33(70) \\
14(30)\end{array}$ & $\begin{array}{l}34(67) \\
17(33)\end{array}$ & 0.82 \\
\hline Charlson Comorbidity Index (value; mean \pm SD) & $2.53 \pm 2.00$ & $3.72 \pm 2.33$ & 0.02 \\
\hline $\mathrm{ICU}^{\mathrm{b}}$ stay (days; mean $\pm \mathrm{SD}$ ) & $15.89 \pm 11.31$ & $10.65 \pm 8.56$ & 0.01 \\
\hline \multicolumn{4}{|l|}{ Season of hospitalization $(n, \%)$} \\
\hline Spring & $14(56)$ & $11(44)$ & \\
\hline Summer & $10(59)$ & $7(41)$ & \\
\hline Autumn & $9(60)$ & $6(40)$ & \\
\hline Winter & $14(34)$ & $27(66)$ & \\
\hline Overall 30-day mortality (n, \%) & $47(48)$ & $51(52)$ & \\
\hline
\end{tabular}

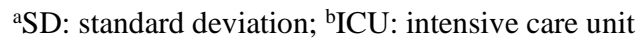


Table 2

Clinical findings in patients with severe community-acquired pneumonia by the outcome

\begin{tabular}{|c|c|c|c|}
\hline & $\begin{array}{c}\text { Survivors } \\
\mathrm{n}=47\end{array}$ & $\begin{array}{c}\text { Non-survivors } \\
\mathrm{n}=51\end{array}$ & P-value \\
\hline Body temperature $\left({ }^{\circ} \mathrm{C} ;\right.$ mean $\left.\pm \mathrm{SD}^{\mathrm{a}}\right)$ & $37.79 \pm 0.98$ & $37.35 \pm 0.86$ & 0.47 \\
\hline Heart rate (beats/min; mean $\pm \mathrm{SD}$ ) & $107.74 \pm 21.09$ & $110.39 \pm 23.53$ & 0.56 \\
\hline Respiratory rate (breaths/min; mean \pm SD) & $32.11 \pm 11.11$ & $30.67 \pm 6.84$ & 0.43 \\
\hline $\begin{array}{l}\text { Signs of shock } \\
\text {-with shock (n, \%) } \\
\text {-without shock }(n, \%) \\
\end{array}$ & $\begin{array}{r}5(23) \\
42(55) \\
\end{array}$ & $\begin{array}{l}17(77) \\
34(45) \\
\end{array}$ & 0.01 \\
\hline $\begin{array}{l}\text { Mental status } \\
\text {-altered (n, \%) } \\
\text {-normal }(\mathrm{n}, \%)\end{array}$ & $\begin{array}{r}9(26) \\
38(59)\end{array}$ & $\begin{array}{l}25(74) \\
26(41)\end{array}$ & 0.01 \\
\hline
\end{tabular}

${ }^{\text {aSD: }}$ standard deviation

Table 3

Biochemical parameters of patients with severe community-acquired pneumonia by the outcome

\begin{tabular}{|c|c|c|c|}
\hline Parameter & $\begin{array}{c}\text { Survivors } \\
n=47\end{array}$ & $\begin{array}{c}\text { Non-survivors } \\
\mathrm{n}=51\end{array}$ & P-value \\
\hline Leucocyte count $\left(\mathrm{x} 10^{9} / \mathrm{L} ;\right.$ mean $\left.\pm \mathrm{SD}^{\mathrm{a}}\right)$ & $12.96 \pm 7.08$ & $14.98 \pm 10.72$ & 0.27 \\
\hline Platelets $\left(\times 10^{9} / \mathrm{L} ;\right.$ mean \pm SD $)$ & $242.70 \pm 133.75$ & $192.65 \pm 95.53$ & 0.03 \\
\hline Glucose (mmol/L; mean \pm SD) & $8.26 \pm 3.84$ & $9.51 \pm 4.95$ & 0.16 \\
\hline Urea $(\mathrm{mmol} / \mathrm{L} ;$ mean $\pm \mathrm{SD})$ & $11.18 \pm 8.17$ & $13.95 \pm 8.66$ & 0.10 \\
\hline Creatinine $(\mathrm{mmol} / \mathrm{L} ;$ mean $\pm \mathrm{SD})$ & $111.60 \pm 80.29$ & $137.22 \pm 110.49$ & 0.19 \\
\hline $\mathrm{ALT}^{\mathrm{b}}(\mathrm{IU} / \mathrm{L} ;$ mean $\pm \mathrm{SD})$ & $60.70 \pm 61.23$ & $104.62 \pm 222.09$ & 0.19 \\
\hline $\mathrm{AST}^{\mathrm{c}}(\mathrm{IU} / \mathrm{L} ;$ mean $\pm \mathrm{SD})$ & $67.24 \pm 53.78$ & $165.84 \pm 398.91$ & 0.09 \\
\hline Albumin $(\mathrm{gr} / \mathrm{L} ;$ mean $\pm \mathrm{SD})$ & $28.57 \pm 5.32$ & $28.41 \pm 6.05$ & 0.90 \\
\hline $\mathrm{LDH}^{\mathrm{d}}(\mathrm{IU} / \mathrm{L} ;$ mean $\pm \mathrm{SD})$ & $1320.63 \pm 795.74$ & $2153.04 \pm 3282.19$ & 0.10 \\
\hline $\mathrm{CRP}^{\mathrm{e}}(\mathrm{mg} / \mathrm{L} ;$ mean $\pm \mathrm{SD})$ & $255.28 \pm 152.45$ & $227.42 \pm 154.92$ & 0.37 \\
\hline $\mathrm{PCT}^{\mathrm{f}}(\mathrm{ng} / \mathrm{mL} ;$ mean $\pm \mathrm{SD})$ & $14.46 \pm 23.75$ & $26.36 \pm 58.17$ & 0.42 \\
\hline Lactates (mmol/L;mean \pm SD) & $2.45 \pm 1.22$ & $3.31 \pm 2.62$ & 0.04 \\
\hline $\mathrm{pH}$ (value; mean $\pm \mathrm{SD}$ ) & $7.41 \pm 0.10$ & $7.36 \pm 0.13$ & 0.04 \\
\hline $\mathrm{PaO}_{2} / \mathrm{FiO}_{2}$ ratio (value; mean $\pm \mathrm{SD}$ ) & $142.91 \pm 93.15$ & $121.60 \pm 73.64$ & 0.21 \\
\hline
\end{tabular}

${ }^{\mathrm{a} S D}$ : standard deviation, ${ }^{\mathrm{b}} \mathrm{ALT}$ : alanine transferase, ${ }^{\mathrm{c}} \mathrm{AST}$ : asparat transferase, ${ }^{\mathrm{d}} \mathrm{LDH}$ : lactate dehydrogenase, ${ }^{\mathrm{e}} \mathrm{CRP}$ : C-reactive protein, ${ }^{\mathrm{f} C T}$ : procalcitonin 
Table 4

Severity indexes in patients with severe community-acquired pneumonia stratified by the outcome

\begin{tabular}{|c|c|c|c|}
\hline Index & $\begin{array}{c}\text { Survivors } \\
\mathrm{n}=47\end{array}$ & $\begin{array}{c}\text { Non-survivors } \\
\mathrm{n}=51\end{array}$ & $\mathrm{P}$-value \\
\hline SAPS II (value; mean \pm SD $^{\mathrm{b}}$ ) & $35.95 \pm 14.33$ & $48.68 \pm 12.96$ & 0.001 \\
\hline $\mathrm{SOFA}^{\mathrm{c}}$ (value; mean $\pm \mathrm{SD}$ ) & $5.0 \pm 2.59$ & $7.82 \pm 3.69$ & 0.001 \\
\hline $\mathrm{MPM}^{\mathrm{d}}$ (value; mean $\pm \mathrm{SD}$ ) & $18.61 \pm 17.32$ & $33.10 \pm 20.77$ & 0.001 \\
\hline MPM24e (value; mean \pm SD) & $21.57 \pm 20.05$ & $40.43 \pm 24.37$ & 0.001 \\
\hline CURB-65 (value; mean \pm SD) & $2.03 \pm 1.16$ & $2.65 \pm 0.95$ & 0.024 \\
\hline $\operatorname{SCAP}^{\mathrm{g}}$ (value; mean $\pm \mathrm{SD}$ ) & $10.80 \pm 10.69$ & $27.86 \pm 11.06$ & 0.001 \\
\hline
\end{tabular}

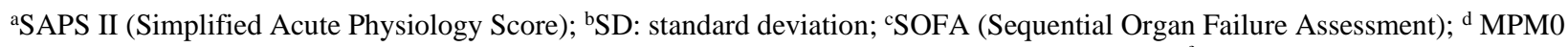
(Mortality Prediction Model at admission), ${ }^{\mathrm{e} M P M} 24$ (Mortality Prediction Model after 24 hours); ${ }_{\mathrm{f}} \mathrm{CURB}-65$ (Confusion, Urea, Respiration rate, Blood Pressure, Age $\geq 65$ years); ${ }^{g}$ Severe Community-Acquired Pneumonia Score (SCAP)

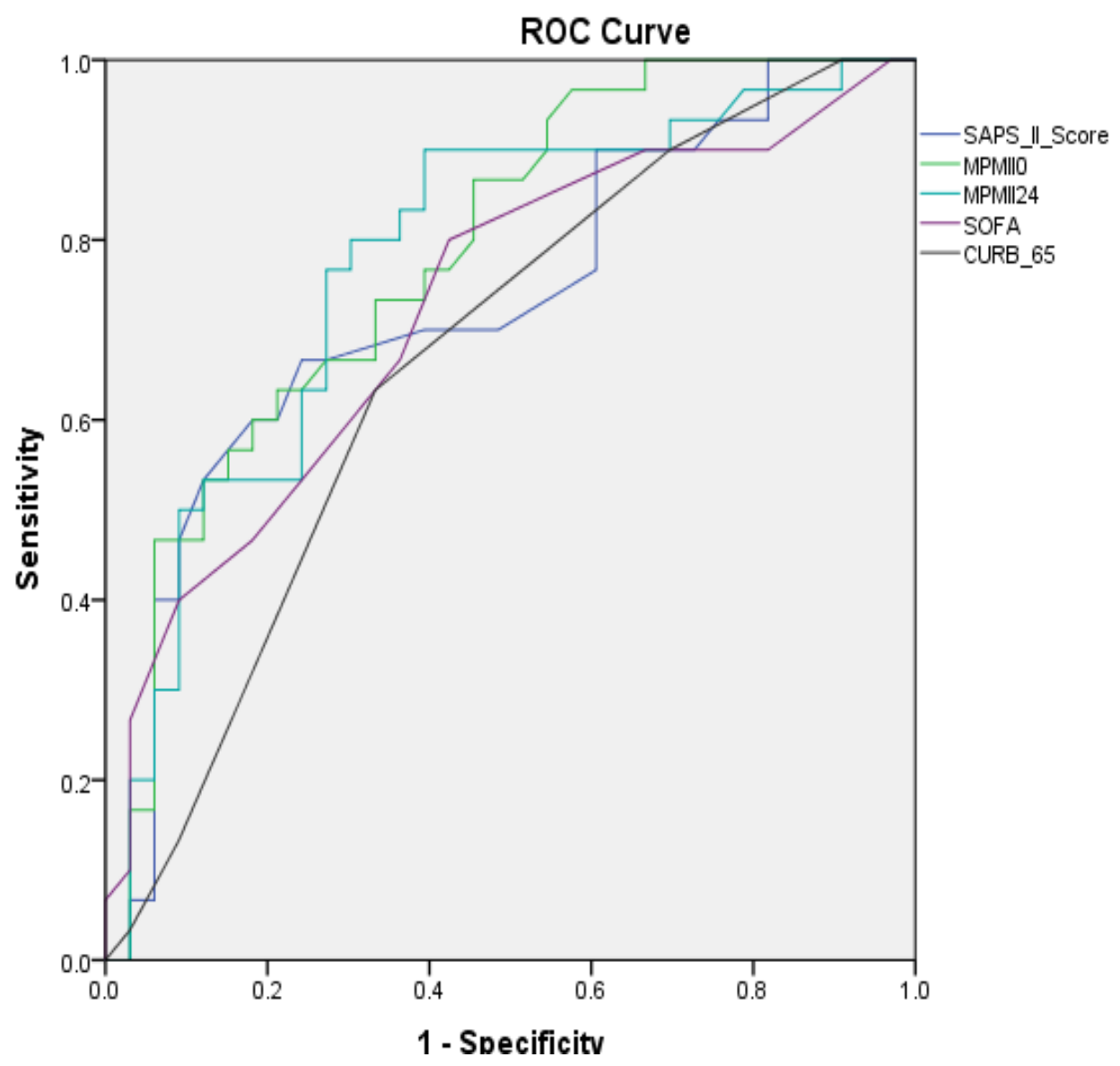

Figure 1. ROC analyses of severity indexes in patients with severe community acquired pneumonia. 
Table 5

Areas Under Curves of severity indexes in patients with severe community acquired pneumonia

\begin{tabular}{lcccc} 
Variable & Area & Std. Error $^{\mathrm{a}}$ & Asymptotic Sig. $^{\mathrm{b}}$ & 95\% Confidence Interval \\
\hline SAPS II & 0.73 & 0.06 & 0.002 & $0.60-0.85$ \\
\hline MPMII0 & 0.78 & 0.05 & 0.001 & $0.67-0.89$ \\
\hline MPMII24 & 0.77 & 0.06 & 0.001 & $0.66-0.89$ \\
\hline SOFA & 0.72 & 0.06 & 0.002 & $0.60-0.85$ \\
\hline CURB-65 & 0.67 & 0.06 & 0.021 & $0.53-0.80$ \\
\hline
\end{tabular}

a. Under the nonparametric assumption

b. Null hypothesis: true area $=0.5$

\section{DISCUSSION}

Community acquired pneumonia remains one the leading causes of death worldwide, thus a successful management requires an accurate assessment of disease severity. A primary goal of this study was to evaluate the predictive ability of the most commonly used severity scoring systems in patients with severe community acquired pneumonia. SAPS II, MPM0, MPM24, SOFA, SCAP and CURB-65 were analysed in the first 24 hours of patient's hospital admission. The key finding of the analysis was that the tested severity indexes adequately identified patients with pneumonia who have a high risk of poor outcome, they all have a similar predictive capacity, but none of them showed superiority over the others regarding mortality prediction.

In our study, 30-day mortality was $52 \%$, which is high, but it is still within the range of published data $[18,19,20]$. This high mortality rate can be explained with the fact that the study analysed a relatively small number of patients from only one centre in a tertiary health institution, and additionaly the study was conducted at the only intensive care unit in the country for patients with the most severe infectious diseases, including patients with complications such as septic shock and ARDS, patients who need mechanical ventilation, haemodialysis etc.

The mean age of the patients was $59.08 \pm$ 15.76 years and males were predominant with 68 $\%$. However, gender and age did not show association with the outcome, unlike many studies which report advanced age as an independent risk factor $[19,21]$. The reason for this discrepancy in the results could be the design of the analysed sample, meaning that the age was not a limiting factor in this study, but it included all patients above the age of 18. Similar to the findings of our study, Brancarti and associates noted that even after a two-year observation, age has shown no correlation with the mortality rate of patients with community acquired pneumonia [22].

The severity of the comorbidities and prediction of 10-year survival were assessed by Charlson comorbidity index, which showed a higher value in patients that died and correlated with an increased risk of poor outcome. This result corresponds with the studies that confirm the predictive value of Charlson comorbidity index in patients with pneumonia [23,24]. Clinical parameters which showed statistically significant difference between the deceased and the survived patients were encephalopathy and septic shock. These findings are in agreement with published data which suggest that patients with multiple organ dysfunction, sepsis/septic shock, respiratory failure and decompensated comorbidity have a higher risk for death [25-27]. Biochemical parameters that showed a significant association with the mortality were platelets count, serum lactates and $\mathrm{pH}$ value as markers of acidosis, a result which has also been confirmed in several studies $[28,29]$. Biomarkers such as leukocytes, procalcitonin and C-reactive protein were not significantly associated with the mortality in our study, although there was a difference in the values registered between the deceased and the survived patients. There are variable data regarding the significance of these biomarkers as outcome predictors. Most studies suggest that procalcitonin is more sensitive than the 
C-reactive protein in differentiating the bacterial etiology of pneumonia, but that both have little correlation with the severity and the outcome of the disease [30-32].

Severity scoring models SAPS II, SOFA, MPM0, MPM24, SCAP and CURB-65 score were evaluated in our study. With logistic regression all indexes proved to have a significant association with the mortality and all were identified as independent outcome predictors. Many studies analyse and compare these scores in order to determine the superior one for mortality prediction but they report different results regarding their specificity, sensitivity and predictive values. Some suggest that the PSI score better identifies low mortality rate in young patients without comorbidities, whereas the CURB score is more useful in elderly and more severe patients [33-35]. On the other hand, the ATS criteria and SCAP show better prediction of hospitalization at intensive care units $[36,37,38]$. In order to compare the predictive values of the severity indexes analyzed in this study, we conducted a ROC analysis and found area under a curve for each index individually as follows: 0.670 for CURB-65, 0.732 for SAPS II, 0.726 for SOFA, 0.785 for MPM0, and 0.777 for MPM24 score. This result corresponds with the data from the studies that confirm the similarity between these indexes in their ability to predict the mortality in patients with severe community acquired pneumonia [39-42].

\section{CONCLUSION}

Severity scoring systems commonly used to predict mortality in patients with community acquired pneumonia were found to be equally effective for the purpose of this study. These indexes provide more objective assessment of disease severity and contribute in clinical practice for early and accurate identification of patients with increased risk of poor outcome.

Introducere. Scopul studiului a fost de evalua capacitatea predictivă a scorurilor de severitate ale pneumoniei pentru mortalitatea la 30 zile

Metode. Au fost incluși 98 de pacienți cu vârste peste 18 ani, diagnosticați cu pneumonie comunitară și spitalizați pe parcursul a trei ani în secția de terapie intensivă a Spitalului Clinic de Boli Infecțioase din Skopje. Au fost înregistrate date demografice, clinice și biochimice. Au fost calculate cinci scoruri de severitate la internare CURB 65 (Confusion, Urea, Respiratory Rate, Blood pressure, Age $\geq 65$ years), SCAP (Severe Community Acquired Pneumonia Score), SAPS II (Simplified Acute Physiology Score), SOFA (Sequential Organ Failure Assessment Score) și MPM (Mortality Prediction Model). Efectul primar căutat a fost mortalitatea la 30 zile de la internare.

Rezultate. Pacienții au avut vârstă medie de 59,08 \pm 15,76 și au fost preponderent bărbați (68\%). Mortalitatea la 30 de zile a fost de $52 \%$. Indexul de comorbiditate Charlson era mai mare la pacienții non-supraviețitori $(3,72 \pm 2,33)$. Toate scorurile de severitate au fost mai mari la pacienții care au decedat. AUC pentru mortalitatea la 30 de zile pentru scoruri a fost de 0,670, 0,732, 0,726, 0,785 și, respectiv, 0,777 .

Concluzii. Scorurile de severitate au detectat pacienții cu pneumonie ce au avut risc de a dezvolta complicații severe, însă niciunul nu a fost superior.

Correspondence to: Katerina Spasovska, MD, MSc, University Clinic for Infectious Diseases, Faculty of Medicine, University of Ss Cyril and Methodius, Bul. Majka Tereza br 17, 1000 Skopje, North Macedonia

E-mail: kspasovskamk@yahoo.com

Tel: + 38971223 277, Fax: + 38923228224

Conflict of interest disclosure: The authors declare that there are not conflicts of interest.

\section{REFERENCES}

1. ASHLEY C. RIDER, BRADLEY W. FRAZEE. Community-acquired pneumonia. Emerg Med Clin North Am. 2018 Nov; 36(4): 665-683.

2. PRINA E, RANZANI OT, TORRES A. Community-acquired pneumonia. Lancet. 2015 Sep 12;386(9998):1097-108.

3. MUSHER DM, THORNER AR. Community-acquired pneumonia. N Engl J Med. 2014 Oct 23; 371(17):1619-28. 
4. JOSE GARNACHO-MONTERO, IRENE BARRERO-GARCÍA, MARIA DE GRACIA GÓMEZ-PRIETO \& IGNACIO MARTÍN-LOECHES. Severe community-acquired pneumonia: current management and future therapeutic alternatives, Expert Review of Anti-infective Therapy, 2018 Sept;16(9):667-677.

5. MORGAN AJ, GLOSSOP AJ. Severe community-acquired pneumonia.BJA Education.2016; 16(5): 167-172.

6. EWIG S, SCHAFER H, TORRES A. Severity assessment in community-acquired pneumonia. Eur Respir J. 2000; 16(6):1193-201.

7. NEUHAUS T, EWIG S. Defining severe community-acquired pneumonia. Med Clin North Am. 2001;85(6):1413-25.

8. METLAY JP et al. Diagnosis and Treatment of Adults with Community-acquired Pneumonia. An Official Clinical Practice Guideline of the American Thoracic Society and Infectious Diseases Society of America. Am J Respir Crit Care Med. 2019 Oct 1;200(7):e45-e67.

9. FINE MJ, AUBLE TE, YEALY DM, et al. A prediction rule to identify low-risk patients with community-acquired pneumonia. N Engl J Med. 1997; 336:243-250.

10. British Thoracic Society Standards of Care Committee. BTS Guidelines for the Management of Community Acquired Pneumonia in Adults. Thorax. 2001;56 Suppl 4: IV1-64.

11. ESPAÑA PP, CAPELASTEGUI A, GORORDO I, ESTEBAN C, ORIBE M, ORTEGA M, BILBAO A, QUINTANA JM. Development and validation of a clinical prediction rule for severe community-acquired pneumonia. Am J Respir Crit Care Med. 2006 Dec 1;174(11):1249-56.

12. NIEDERMAN MS, MANDELL LA, ANZUETO A et al. American Thoracic Society. Guidelines for the management of adults with community-acquired pneumonia. Diagnosis, assessment of severity, antimicrobial therapy, and prevention. Am J Respir Crit Care Med. 2001 Jun; 163(7):1730-54.

13. LE GALL JR, LEMESHOW S, SAULNIER F. A new Simplified Acute Physiology Score (SAPS II) based on a European/North American multicenter study. JAMA. 1993 Dec 22-29;270(24):2957-63.

14. LAMBDEN S, LATERRE PF, LEVY MM, FRANCOIS B. The SOFA score-development, utility and challenges of accurate assessment in clinical trials. Crit Care. 2019 Nov 27;23(1):374.

15. GODINJAK A, IGLICA A, RAMA A, TANČICA I, JUSUFOVIĆ S, AJANOVIĆ A, KUKULJAC A. Predictive value of SAPS II and APACHE II scoring systems for patient outcome in a medical intensive care unit. Acta Med Acad. 2016 Nov;45(2):97-103.

16. SALLUH JI, SOARES M. ICU severity of illness scores: APACHE, SAPS and MPM. Curr Opin Crit Care. 2014 Oct;20(5):557-65.

17. GROZDANOVSKI K, MILENKOVIC Z, STOJOVSKA KALAMARAS P at al. Findings after the analysis of the structure of the patients hospitalized in a six-year period. MMR 2003;53 (Supp 37):178-179.

18. MORTENSEN EM, COLEY CM, SINGER DE, et al. Causes of death for patients with community-acquired pneumonia: results from the Pneumonia Patient Outcomes Research Team cohort study. Arch Intern Med 2002;162: 1059-1064.

19. KOTHE H, BAUER T, MARRE R, SUTTORP N, WELTE T, DALHOFF K; Competence Network for Community-Acquired Pneumonia study group. Outcome of community acquired pneumonia: influence of age, residence status and antimicrobial treatment. Eur Respir J. 2008 Jul;32(1):139-46.

20. PATTERSON C.M., LOEBINGER M.R. Community acquired pneumonia: Assessment and treatment. Clin Med (Lond). 2012 Jun;12(3):283-6.

21. KOLDITZ M, EWIG S, KLAPDOR B, SCHUTTE H, WINNING J, RUPP J et al. Community-acquired pneumonia as medical emergency: predictors of early deterioration. Thorax 2015; 70: 551-58.

22. BRANCARTI FL, CHOW JW, WAGENER MM, et al. Is pneumonia really the old man's friend? Two-year prognosis after community-acquired pneumonia. Lancet $1993 ; 342: 30-33$.

23. BAHLIS LF, DIOGO LP, FUCHS SC. Charlson Comorbidity Index and other predictors of in-hospital mortality among adults with community-acquired pneumonia. J Bras Pneumol. 2021 Feb 24;47(1):e20200257.

24. WESEMANN T, NÜLLMANN H, PFLUG MA, HEPPNER HJ, PIENTKA L, THIEM U. Pneumonia severity, comorbidity and 1-year mortality in predominantly older adults with community-acquired pneumonia: a cohort study. BMC Infect Dis. 2015;15:2.

25. MULLER B, HARBARTH S, STOLZ D, BINGISSER R, MUELLER C, LEUPPI J, NUSBAUMER C, TAMM M, CHRISTCRAIN M. Diagnostic and prognostic accuracy of clinical and laboratory parameters in community-acquired pneumonia. BMC Infect Dis. 2007; 7:10.

26. ABDEL AZIZ AO, ABDEL FATTAH M T, MOHAMED AH, ABDEL AZIZ MO, MOHAMMED MS. Mortality predictors in patients with severe community-acquired pneumonia requiring ICU admission. Egypt J Bronchology, 2016; 10 (2): $155-161$.

27. ITO A, ISHIDA T, TOKUMASU H, WASHIO Y, YAMAZAKI A, ITO Y, TACHIBANA H. Prognostic factors in hospitalized community-acquired pneumonia: a retrospective study of a prospective observational cohort. BMC Pulm Med. 2017 May 2;17(1):78.

28. NING P, ZHENG Y, LUO Q, LIU X, KANG Y, ZHANG Y, ZHANG R, XU Y, YANG D, XI W, WANG K, CHEN Y, AN S, GAO Z. Metabolic profiles in community-acquired pneumonia: developing assessment tools for disease severity. Crit Care. 2018 May 14;22(1):130.

29. HUANG Y, LIU A, LIANG L, JIANG J, LUO H, DENG W, LIN G, WU M, LI T, JIANG Y. Diagnostic value of blood parameters for community-acquired pneumonia. Int Immunopharmacol. 2018 Nov;64:10-15.

30. UGAJIN M, YAMAKI K, HIRASAWA N, YAGI T. Predictive values of semi-quantitative procalcitonin test and common biomarkers for the clinical outcomes of community-acquired pneumonia. Respir Care. 2014;59: 564-73.

31. SIBILA O, RESTREPO MI. Biomarkers in community-acquired pneumonia: still searching for the one. Eur Respir J. 2019 Feb 28; 53(2):1802469.

32. AKAGI T, NAGATA N, MIYAZAKI H, HARADA T, TAKEDA S, YOSHIDA Y, WADA K, FUJITA M, WATANABE K. Procalcitonin is not an independent predictor of 30-day mortality, albeit predicts pneumonia severity in patients with pneumonia acquired outside the hospital. BMC Geriatr. 2019 Jan 7;19(1):3.

33. AUJESKY D, AUBLE TE, YEALY DM, STONE RA, OBROSKY DS, MEEHAN TP, et al. Prospective comparison of three validated prediction rules for prognosis in community-acquired pneumonia. Am J Med 2005; 118: 384-92.

34. MAN SY, LEE N, IP M, ANTONIO GE, CHAU SS, MAK P, et al. Prospective comparison of three predictive rules for assessing severity of community-acquired pneumonia in Hong Kong. Thorax 2007; 62: 348-53. 
35. BUISING KL, THURSKY KA, BLACK JF, MACGREGOR L, STREET AC, KENNEDY MP, et al. A prospective comparison of severity scores for identifying patients with severe community acquired pneumonia: reconsidering what is meant by severe pneumonia. Thorax 2006; 61: 419-24.

36. ESPANA PP, CAPELASTEGUI A, QUINTANA JM, BILBAO A, DIEZ R, PASCUAL S, et al. Validation and comparison of SCAP as a predictive score for identifying low-risk patients in community-acquired pneumonia. J Infect 2010; 60: 106-13.

37. CHALMERS JD, MANDAL P, SINGANAYAGAM A, AKRAM AR, CHOUDHURY G, SHORT PM, HILL AT: Severity assessment tools to guide ICU admission in community-acquired pneumonia: systematic review and meta-analysis. Intensive Care Med 2011, 37:1409-1420.

38. MARTI et al. Prediction of severe community-acquired pneumonia: a systematic review and meta-analysis. Critical Care 2012, 16: R141.

39. KĄDZIOŁKA I, ŚWISTEK R, BOROWSKA K, TYSZECKI P, SEREDNICKI W. Validation of APACHE II and SAPS II scales at the intensive care unit along with assessment of SOFA scale at the admission as an isolated risk of death predictor. Anaesthesiol Intensive Ther. 2019;51(2):107-111.

40. ALICI IO, CAPAN N, ERTURK A, CANBAKAN S. Comparison of Severity Scoring Systems in Community-Acquired Pneumonia. Eurasian J Pulmonol 2015; 17: 15-21.

41. HANIFFA R, ISAAM I, DE SILVA AP, DONDORP AM, DE KEIZER NF. Performance of critical care prognostic scoring systems in low and middle-income countries: a systematic review. Crit Care. 2018 Jan 26;22(1):18.

42. KEEGAN MT, GAJIC O, AFESSA B. Severity of illness scoring systems in the intensive care unit. Crit Care Med. 2011 Jan;39(1):163-9.

Received $4^{\text {th }}$ May 2021 